\title{
Fosphenytoin-induced dyskinesias in an infant with Sturge-Weber syndrome
}

自

Figure 1 MRI findings in Sturge-Weber syndrome

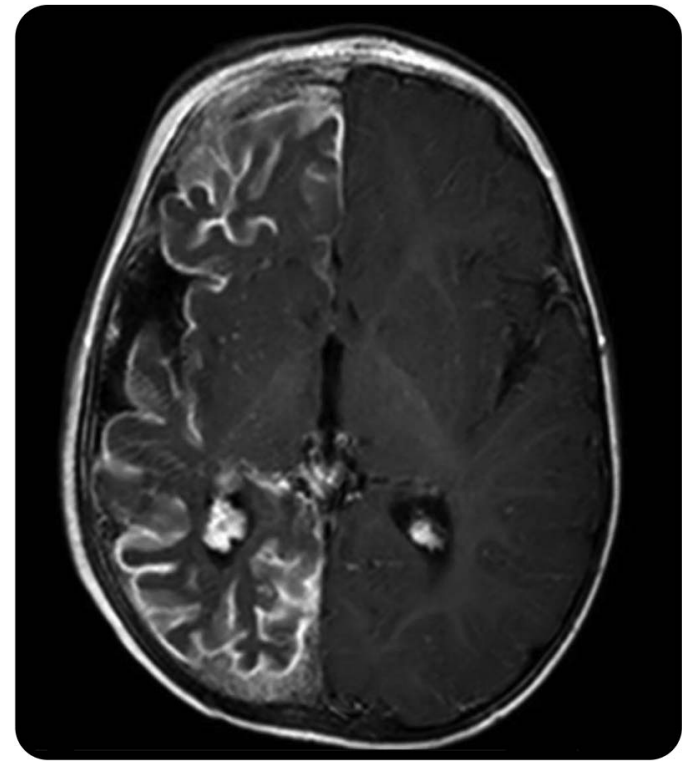

T1 postcontrast MRI illustrating right hemispheric cerebral angiomatosis.

Phenytoin-induced dyskinesias are uncommon and underrecognized. ${ }^{1}$ An 11-month-old girl with SturgeWeber syndrome (figure 1) and left hemiparesis had prolonged pharmacoresistant seizures. After IV fosphenytoin (peak level $=17.9 \mu \mathrm{g} / \mathrm{mL}$, free level not obtained), she developed right hemi-dyskinesias with nystagmoid eye movements that stopped during sleep (video on the Neurology ${ }^{\circledR}$ Web site at Neurology.org).

Figure 2 EEG findings

Supplemental data at Neurology.org

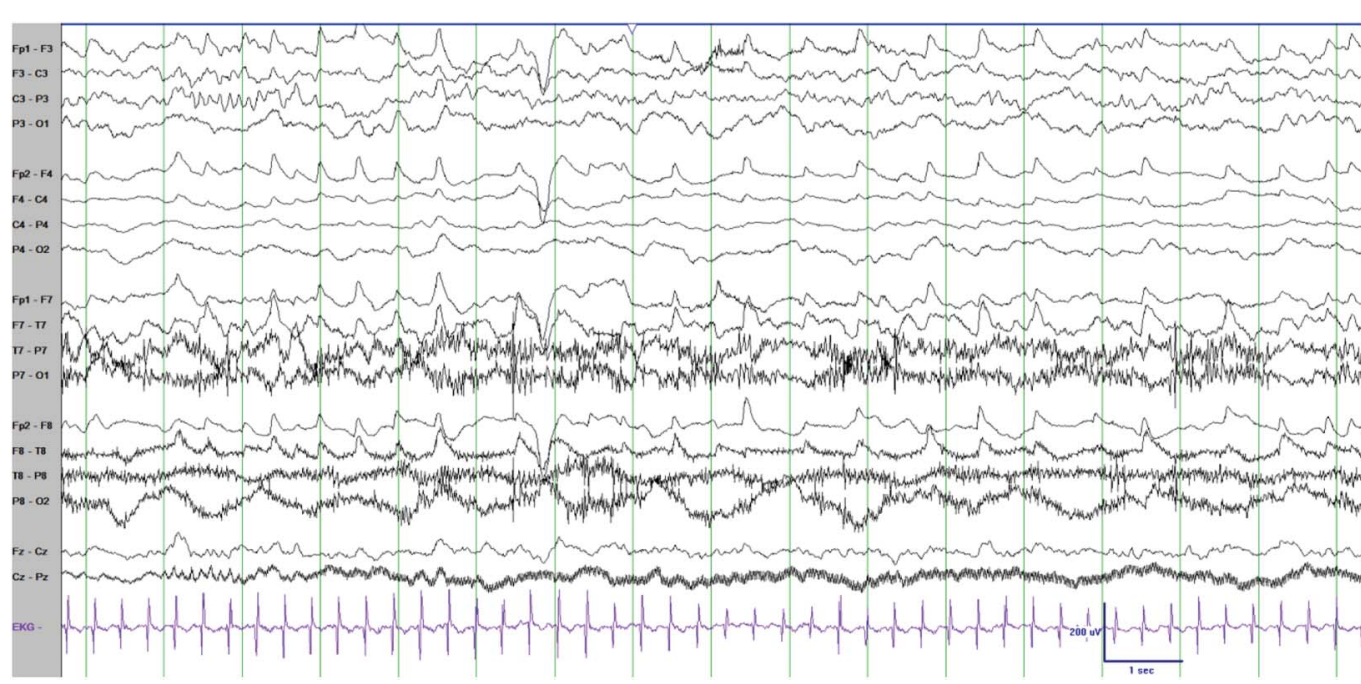

The EEG during the dyskinetic reaction showed no ictal correlate. Note the decreased amplitudes over the right cerebral hemisphere with frequent nystagmoid eye movement artifact. 
Video-EEG showed no ictal change (figure 2). Concurrent medications included oxcarbazepine, levetiracetam, and valproic acid. The movements resolved 8 hours after discontinuing fosphenytoin. Right cerebral infarction was the presumed underlying cause of phenytoin-induced hemi-dyskinesia. Diagnosis of phenytoin-induced dyskinesias requires a high index of suspicion and typically resolves upon medication discontinuation.

Drew M. Thodeson, MD, David C. Reiber, REEGT, Alison M. Dolce, MD, Deepa Sirsi, MD

From the Department of Neurology (D.M.T., A.M.D., D.S.), Division of Pediatric Epilepsy and Clinical Neurophysiology, University of Texas Southwestern Medical Center; and Department of Neurophysiology (D.C.R.), Children's Medical Center Dallas, TX.

Author contributions: Dr. Drew Thodeson: writing the manuscript, selecting and collecting images and video files, and patient consent. David Reiber: patient care and video editing. Dr. Alison Dolce: critical revision of the manuscript. Dr. Deepa Sirsi: critical revision of the manuscript.

Study funding: No targeted funding reported.

Disclosure: The authors report no disclosures relevant to the manuscript. Go to Neurology.org for full disclosures.

Correspondence to Dr. Thodeson: drew.thodeson@gmail.com

1. Krishnamoorthy KS, Zalneraitis EL, Young RSK, Bernad PG. Phenytoin-induced choreoathetosis in infancy: case reports and a review. Pediatrics 1983;72:831-834.

\section{Get Connected. Stay Connected.}

Connect with the American Academy of Neurology's popular social media channels to stay up-todate on the latest news and breakthroughs in neurology, and network with peers and neurology thought leaders. Visit $A A N$.com/Connect.
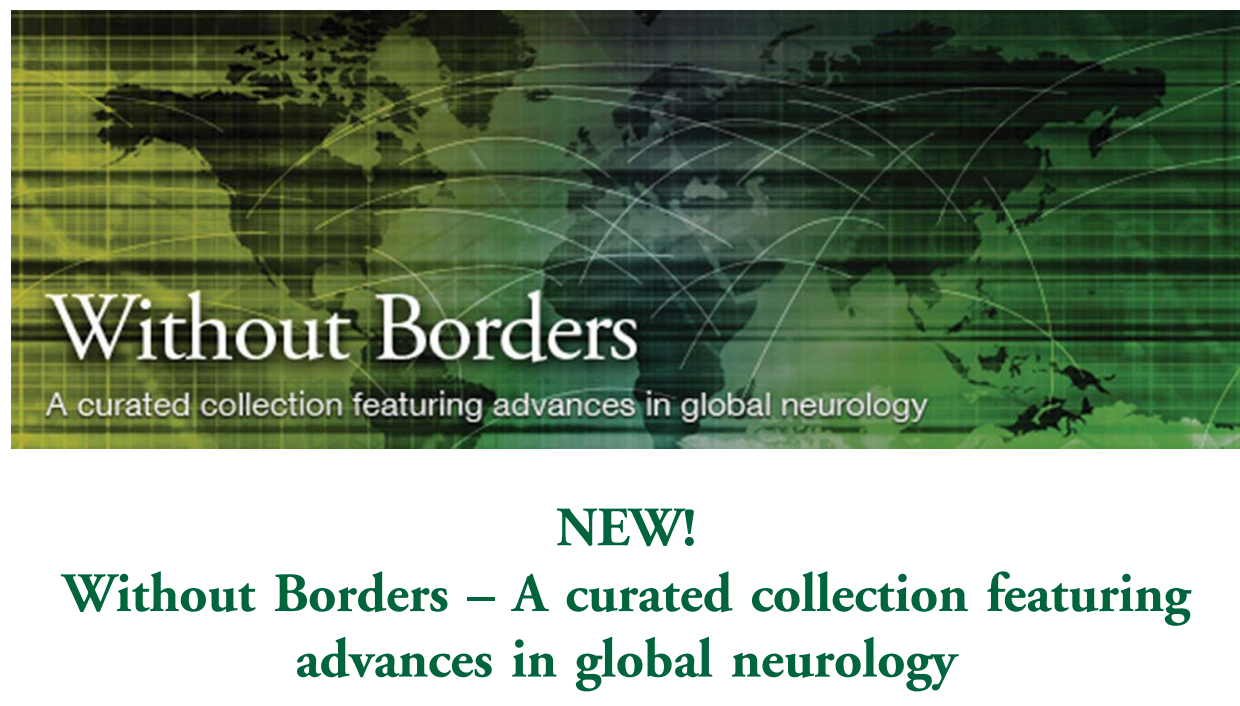

This Neurology ${ }^{\circledR}$ special interest Web site is the go-to source for tracking science and politics of neurology beyond the United States, featuring up-to-the-minute blogs, scholarly perspectives, and academic review of developments and research from Neurology journals and other sources. Curated by Gretchen L. Birbeck, MD, MPH.

Expand your world view at Neurology.org/woborders. 


\section{Neurology}

\section{Fosphenytoin-induced dyskinesias in an infant with Sturge-Weber syndrome \\ Drew M. Thodeson, David C. Reiber, Alison M. Dolce, et al. \\ Neurology 2016;86;1561-1562 \\ DOI 10.1212/WNL.0000000000002595}

\section{This information is current as of April 18, 2016}

\begin{tabular}{|c|c|}
\hline $\begin{array}{l}\text { Updated Information \& } \\
\text { Services }\end{array}$ & $\begin{array}{l}\text { including high resolution figures, can be found at: } \\
\text { http://n.neurology.org/content/86/16/1561.full }\end{array}$ \\
\hline Supplementary Material & $\begin{array}{l}\text { Supplementary material can be found at: } \\
\text { http://n.neurology.org/content/suppl/2016/04/16/WNL. } 0000000000002 \\
\text { 595.DC1 }\end{array}$ \\
\hline References & $\begin{array}{l}\text { This article cites } 1 \text { articles, } 0 \text { of which you can access for free at: } \\
\text { http://n.neurology.org/content/86/16/1561.full\#ref-list-1 }\end{array}$ \\
\hline Subspecialty Collections & $\begin{array}{l}\text { This article, along with others on similar topics, appears in the } \\
\text { following collection(s): } \\
\text { All Clinical Neurology } \\
\text { http://n.neurology.org/cgi/collection/all_clinical_neurology } \\
\text { All Movement Disorders } \\
\text { http://n.neurology.org/cgi/collection/all_movement_disorders } \\
\text { All Pediatric } \\
\text { http://n.neurology.org/cgi/collection/all_pediatric } \\
\text { Antiepileptic drugg } \\
\text { http://n.neurology.org/cgi/collection/antiepileptic_drugs }\end{array}$ \\
\hline Permissions \& Licensing & $\begin{array}{l}\text { Information about reproducing this article in parts (figures,tables) or in } \\
\text { its entirety can be found online at: } \\
\text { http://www.neurology.org/about/about_the_journal\#permissions }\end{array}$ \\
\hline Reprints & $\begin{array}{l}\text { Information about ordering reprints can be found online: } \\
\mathrm{http} / / / \mathrm{n} \text {.neurology.org/subscribers/advertise }\end{array}$ \\
\hline
\end{tabular}

Neurology ${ }^{\circledR}$ is the official journal of the American Academy of Neurology. Published continuously since 1951, it is now a weekly with 48 issues per year. Copyright @ 2016 American Academy of Neurology. All rights reserved. Print ISSN: 0028-3878. Online ISSN: 1526-632X.

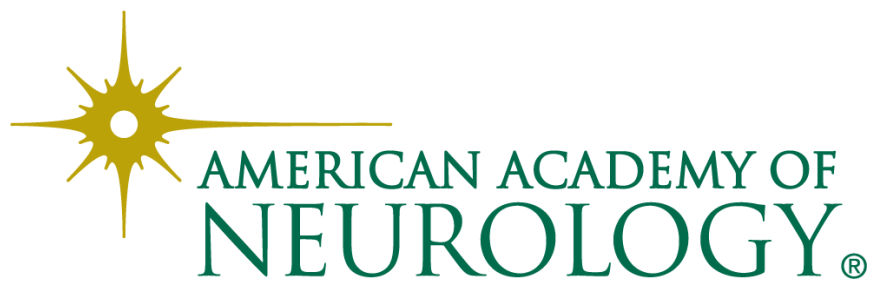

